\title{
Isolasi dan Identifikasi Bakteri Rizosfir Arachis pintoi setelah Inokulasi Mikoriza Arbuskular dan Penambahan Pupuk Organik (Isolation and Identification of Rhizosphere Bacteria in Arachis pintoi after the Inoculation of Arbuscular Mycorrhiza and The Addition of Organic Fertilizer)
}

\author{
Johan Bhayangkara Pelealu1), Regina Rosita Butarbutar ${ }^{1)}$, Trina E. Tallei(1)* \\ 1) Program Studi Biologi, Jurusan Biologi FMIPA UNSRAT Manado, 95115 \\ "Email korespondensi: trina_tallei@unsrat.ac.id
}

Diterima 25 Juli 2017, diterima untuk dipublikasikan 10 Agustus 2017

\begin{abstract}
Abstrak
Arachis pintoi (kacang pinto) sering digunakan sebagai pakan ternak, memiliki kemampuan hidup pada lahan marginal, dan mampu mengembalikan indeks kualitas tanah dari sangat rendah menjadi sedang tinggi, karena adanya bakteri dan fungi yang berperan di lingkungan rizosfir. Penelitian ini bertujuan untuk mengidentifikasi bakteri rizosfir A. pintoi setelah inokulasi mikoriza arbuskular dan penambahan pupuk organik. Kacang pinto ditanam pada tanah yang diberi $20 \mathrm{~g}$ mikoriza arbuskular dan $500 \mathrm{~g}$ pupuk organik untuk setiap $3 \mathrm{~kg}$ tanah di dalam polibag. Setelah tanaman berusia 6 minggu, sebanyak $10 \mathrm{~g}$ tanah diambil dari lingkungan rizosfir kemudian dimasukan ke dalam gelas Erlenmeyer dan ditambahkan dengan $90 \mathrm{ml}$ air suling steril. Sebanyak $1 \mathrm{ml}$ suspensi hasil pengenceran $10^{-5}$ ditebar di atas media Nutrient Agar. Setiap koloni yang tumbuh dimurnikan dan diidentifikasi secara biokimiawi. Dari hasil identifikasi diperoleh 7 jenis bakteri rizosfir yaitu Azotobacter sp., Enterobacter sp., Rhizobium sp., Enterebocter sp., Azospirillum sp., Pseudomonas sp., dan Bacillus sp.

Kata kunci: rizosfir, mikoriza arbuskular, Arachis pintoi, kacang pinto
\end{abstract}

\begin{abstract}
Arachis pintoi (pinto bean) is often used as animal feed, has the ability to live on marginal land, and is able to provide soil quality from very low to high, due to the presence of bacteria and fungi that play a role in the rhizosphere. This study aims to identify the rhizosphere bacteria of A. pintoi after inoculation of arbuscular mycorrhizae and the addition of organic fertilizer. The pinto beans are grown on soil that has been given $20 \mathrm{~g}$ of arbuscular mycorrhizal and $500 \mathrm{~g}$ organic fertilizer for every $3 \mathrm{~kg}$ of soil in polybags. After the plants were 6 weeks old, $10 \mathrm{~g}$ of soil was taken from the rhizosphere environment then placed into the Erlenmeyer glass and added with $90 \mathrm{ml}$ of sterile distilled water. A total of $1 \mathrm{ml} 10^{-5}$ dilution, the suspension was spread over onto Nutrient Agar medium. Each growing colony is purified and identified biochemically. From this, 7 types of rhizosphere bacteria was identified, namely Azotobacter sp., Enterobacter sp., Rhizobium sp., Enterebocter sp., Azospirillum sp., Pseudomonas sp., and Bacillus sp.

Keywords: rhizosphere, arbuscular mycorrhizae, Arachis pintoi, pinto bean

\section{PENDAHULUAN}

Arachis pintoi (kacang pinto) merupakan tumbuhan legum yang sering digunakan sebagai pakan hewan ternak yang memiliki nilai nutrisi yang tinggi. Selain itu,

tumbuhan ini juga digunakan sebagai tumbuhan penutup untuk memicu pemulihan area padang rumput yang mengalami degradasi. Tumbuhan ini mampu beradaptasi pada lahan marjinal dan memiliki kemampuan
\end{abstract}


produksi vegetatif dan multiplikasi melalui stolon (Sales et al. 2013).Seperti halnya tumbuhan legum lainnya, $A$. pintoi memiliki potensi untuk memfiksasi nitrogen dari atmosfir sehingga menghasilkan pakan dengan kualitas gizi yang lebih baik dan membantu dalam peningkatan fertilitas tanah (Jensen et al. 2012). Tumbuhan kacang pinto seringkali dijadikan pakan untuk hewan ternak seperti sapi, kambing, dan kuda. Kandungan proteinnya berkisar antara $18-25 \%$ dan kemampuan digesti materi kering oleh hewan ternak yaitu sekitar $63 \%$ (Heuzé et al. 2016).

Kesuburan tanah dipengaruhi oleh banyak faktor antara lain keanekaragaman dan jumlah mikroba tanah, suhu udara, curah hujan, kelembaban udara, tanah, dan kandungan nutrisi tanah. Ketersediaan karbon (C) yang dihasilkan oleh eksudat akar tumbuhan mempengaruhi lingkungan rizosfir tumbuhan sehingga memberikan kontribusi pada keanekaragaman dan jumlah populasi bakteri penambat $\mathrm{N}$ (Ahemad dan Kibret 2014).

Pupuk inorganik seringkali digunakan untuk meningkatkan kesuburan tanah dan tanaman karena lebih mudah diperoleh dengan harga yang relatif lebih murah dibandingkan dengan pupuk organik (hayati). Akan tetapi, penggunaan pupuk inorganik dapat menyebabkan berkurangnya keanekaragaman dan jumlah mikroorganisme tanah yang memiliki kemampuan untuk membantu penyuburan tanah, misalnya mikroorganisme yang mampu memfiksasi nitrogen. Beberapa penelitian telah dilakukan untuk mengembangkan mikoriza sebagai pupuk organik sebagai pengganti pupuk inorganik, antara lain oleh Tallei et al. (2016). Mikoriza merupakan simbiosis mutualisme antara fungi dengan akar tumbuhan.
Fungi mengkolonisasi sistem perakaran tumbuhan inang dan mengakibatkan adanya peningkatan kemampuan akar dalam menyerap air dan nutrisi. Sementara itu, tumbuhan menyediakan karbohidrat bagi fungi yang dibentuk dari hasil fotosintesis. Mikoriza mampu melindungi tumbuhan inang dari serangan patogen. Pembentukan simbiosis mikoriza arbuskular dipengaruhi oleh rizosfir tumbuhan, baik lingkungan abiotik dan abiotik, termasuk mikroba (Kheyrodin 2014). Pemahaman mengenai interaksi antara mikroorganisme yang mendiami tanah pada lingkungan rizosfir merupakan hal yang penting, karena memiliki peran dalam siklus nutrien.

Populasi mikroorganisme rizosfir biasanya lebih banyak dan beragam dibandingkan pada daerah nonrizosfir. Mikroba rizosfir banyak berperan dalam penyediaan atau penyerapan hara tanaman. Berdasarkan latar belakang tersebut maka penelitian ini dilakukan untuk mengidentifikasi bakteri risozfir tanaman $A$. pintoi setelah inokulasi dengan mikoriza arbuskular dan penambahan pupuk organik.

\section{METODE}

Tanah bagian atas (top soil) yang digunakan untuk penelitian diperoleh dari Kelurahan Batu Kota. Tanah yang diambil yaitu tanah bagian atas dengan kedalaman $20 \mathrm{~cm}$. Tanah kemudian dikeringanginkan selama satu minggu. Tanah yang telah kering diayak menggunakan ayakan kawat dengan ukuran lubang $2 \mathrm{~mm}$. Tanah yang sudah diayak disterilkan dengan cara disangrai, kemudian didinginkan. Tanah yang telah steril dimasukkan ke dalam polybag sebanyak $3 \mathrm{~kg}$.

Penelitian dilakukan dengan lima perlakuan dengan masingmasing tiga ulangan yaitu $\mathrm{FO}=$ tanah 
steril (kontrol); $\mathrm{F} 1=$ tanah steril yang diberi $500 \mathrm{~g}$ pupuk organik; F2 = tanah steril yang dicampur dengan $500 \mathrm{~g}$ pupuk organik dan diinokulasi dengan $20 \mathrm{~g}$ mikoriza arbuskular; F3 $=$ tanah steril yang diinokkulasi dengan $20 \mathrm{~g}$ mikoriza arbuskularr; F4 = tanah yang tidak disangrai dan tidak diberikan mikoriza arbuskular dan pupuk organik. Pada masingmasing polybag ditanami dengan Arachis pintoi sebanyak empat tangkai dengan panjang $30 \mathrm{~cm}$. Tanaman ditanam dengan kedalaman $5 \mathrm{~cm}$. Pemberian pupuk hanya dilakukan sekali diawal percobaan dan penyiraman dilakukan 3 kali seminggu.

\section{Isolasi dan Pemurnian Bakteri}

Tanah rizosfir diperoleh dari tanaman yang berusia 6 minggu dengan cara menggoyangkan tanah yang melekat pada akar tanaman. Tanah sebanyak 10 gram dikumpulkan di dalam gelas Erlenmeyer steril dan ditambahkan dengan 90ml air suling steril. Pengenceran dilakukan sampai $10^{-5}$ dan sebanyak $1 \mathrm{ml}$ suspensi hasil pengenceran tersebut ditebar di atas media NA, lalu diinkubasi selama $2 \times 24$ jam pada suhu $37^{\circ} \mathrm{C}$ di dalam inkubator.

Koloni-koloni bakteri yang tumbuh dominan dan yang tampak berbeda diambil dengan jarum ose kemudian ditanam pada media NA dengan metode streak quadrant untuk mendapatkan koloni murni. Media diinkubasi selama 2x24 jam pada suhu $37^{\circ} \mathrm{C}$. Bakteri yang telah tumbuh pada media agar tersebut yang membentuk koloni tunggal digunakan sebagai kultur murni pada proses identifikasi. Identifikasi bakteri dilakukan berdasarkan morfologi koloni, pewanaan Gram, dan pengujian secara biokimiawi. Pengujian biokimia terdiri atas delapan uji yaitu fermentasi karbohidrat, produksi $\mathrm{H}_{2} \mathrm{~S}$, pembentukan gas, indol, motil, uji licin, uji sitrat, dan uji katalase. Bakteri diidentifikasi menggunakan buku identifikasi Bergey's Manual of Determinative Bacteriology. Analisis dilakukan secara deskriptif.

\section{HASIL DAN PEMBAHASAN}

Hasil pengamatan pada semua perlakuan menunjukkan bahwa terdapat 8 isolat bakteri yang berbeda yang diamati berdasarkan morfologi koloni. Pada perlakuan F0 sebagai kontrol didapati empat isolat bakteri yaitu A, B, D, dan F. Pada perlakuan $F 1$ didapati tiga isolat bakteri, yaitu A, C, D. Pada perlakuan F2 didapati empat isolat bakteri yaitu A, C, E dan H. Pada perlakuan F3 didapati lima isolat bakteri yaitu $A, C$, $D, G$, dan $H$. Pada perlakuan F4 didapati tiga isolat bakteri yaitu $A, B$, dan C (Tabel 1).

Tabel 1. Jumlah dan Kode Isolat Bakteri RizosfirTanaman A. pintoi

\begin{tabular}{|c|c|c|c|c|c|c|c|c|c|}
\hline \multirow[t]{2}{*}{ Perlakuan } & \multirow{2}{*}{$\begin{array}{l}\text { Jumlah } \\
\text { Isolat }\end{array}$} & \multicolumn{8}{|c|}{ Kode Isolat } \\
\hline & & $A$ & $B$ & C & $D$ & $E$ & $F$ & $\mathrm{G}$ & $\mathrm{H}$ \\
\hline F0 & 4 & $\sqrt{ }$ & $\sqrt{ }$ & & $\sqrt{ }$ & & $\sqrt{ }$ & & \\
\hline F1 & 3 & $\sqrt{ }$ & & $\sqrt{ }$ & $\sqrt{ }$ & & & & \\
\hline F2 & 4 & $\sqrt{ }$ & & $\sqrt{ }$ & & $\sqrt{ }$ & & & $\sqrt{ }$ \\
\hline F3 & 5 & $\sqrt{ }$ & & $\sqrt{ }$ & $\sqrt{ }$ & & & $\sqrt{ }$ & $\sqrt{ }$ \\
\hline $\mathrm{F} 4$ & 3 & $\sqrt{ }$ & $\sqrt{ }$ & $\sqrt{ }$ & & & & & \\
\hline
\end{tabular}


Tabel 2. Pewarnaan Gram dan Morfologi Bakteri

\begin{tabular}{ccc}
\hline Isolat & Morfologi Bakteri & Gram \\
\hline A & Basil & - \\
\hline B & Basil & - \\
\hline C & Basil & + \\
\hline D & Basil & - \\
\hline E & Spiral & - \\
\hline F & Basil & - \\
\hline G & Cocus & - \\
\hline H & Basil & - \\
\hline
\end{tabular}

Tabel 3. Hasil Identifikasi Bakteri Rizosfir

\begin{tabular}{|c|c|c|c|c|c|c|c|c|c|}
\hline Isolat & 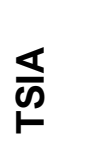 & $\stackrel{\sim}{I}$ & $\stackrel{\mathscr{d}}{\mathbb{J}}$ & 홀 & 응 & 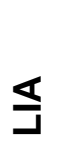 & 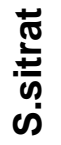 & $\frac{\pi}{\underset{\pi}{\pi}}$ & Jenis \\
\hline$A$ & $\mathrm{~K} / \mathrm{A}$ & - & + & - & - & - & + & - & $\begin{array}{l}\text { Azotobacter } \\
\text { sp. }\end{array}$ \\
\hline$B$ & $\mathrm{~K} / \mathrm{A}$ & - & + & - & - & - & + & - & Rhizobium sp. \\
\hline $\mathrm{C}$ & $\mathrm{A} / \mathrm{A}$ & - & - & - & - & + & + & + & Bacilus sp. \\
\hline$D$ & $\mathrm{~K} / \mathrm{A}$ & - & + & - & - & - & + & + & $\begin{array}{l}\text { Enterobacter } \\
\text { sp. }\end{array}$ \\
\hline$E$ & $\mathrm{~K} / \mathrm{K}$ & - & - & - & - & - & + & - & $\begin{array}{l}\text { Azospirilium } \\
\text { sp. }\end{array}$ \\
\hline $\mathrm{F}$ & $\mathrm{K} / \mathrm{K}$ & - & - & - & - & + & + & + & $\begin{array}{l}\text { Pseudomonas } \\
\text { sp. }\end{array}$ \\
\hline $\mathrm{G}$ & $\mathrm{K} / \mathrm{A}$ & - & + & - & - & + & + & - & $\begin{array}{l}\text { Enterobacter } \\
\text { sp. }\end{array}$ \\
\hline $\mathrm{H}$ & $\mathrm{K} / \mathrm{A}$ & - & + & - & - & - & + & - & $\begin{array}{l}\text { Azotobacter } \\
\text { sp. }\end{array}$ \\
\hline
\end{tabular}

Keterangan: $\mathrm{K} / \mathrm{A}=\mathrm{Alkali} /$ Asam (merah/kuning); $\mathrm{A} / \mathrm{A}=\mathrm{Asam} /$ asam (kuning/kuning); $\mathrm{K} / \mathrm{K}=$ Alkali/alkali (merah/merah)

Berdasarkan hasil pewarnaan Gram, isolat $A, B, D, F$, dan $H$ merupakan bakteri Gram negatif dan berbentuk basil. Isolat $C$ berbentuk basil Gram positif, dan isolat $G$ merupakan bakteri Gram negatif berbentuk cocus sedangkan pada isolat $\mathrm{E}$ merupakan bakteri Gram negatif berbentuk spiral (Tabel 2). Dari hasil identifikasi diperoleh 7 jenis bakteri rizosfir yaitu Azotobacter sp., Enterobacter sp., Rhizobium sp., Enterebocter sp., Azospirillum sp., Pseudomonas sp., dan Bacillus sp. (Tabel 3).
Pada uji katalase diperoleh hasil positif pada isolat $C, D$ dan $F$, yaitu pada saat ditetesi hidrogen peroksida terbentuk gelembung udara. Katalase merupakan enzim yang digunakan mikroorganisme untuk menguraikan hidrogen peroksida menjadi $\mathrm{H}_{2} \mathrm{O}$ dan $\mathrm{O}_{2}$ (Murray et al. 2007). Pada uji lisin diperoleh hasil positif pada isolat $\mathrm{C}, \mathrm{F}$ dan G, yang ditandai dengan terjadinya perubahan warna pada media menjadi ungu. Ini menandakan bahwa isolate isolat bakteri mampu mendekarboksilasi asam amino dan lisin. Pemecahan lisin oleh enzim 
dekarbosilase akan menghasilkan karbon dioksida yang berperan dalam pembentukan dinding sel dan proses metabolisme sel mikroorganisme.

Pada pengujian sitrat, isolat A, B, C, D, E, F, G dan H memberikan hasil positif, ditandai dengan adanya perubahan media menjadi warna biru. Hal tersebut terjadi karena bakteri menggunakan sitrat, yang menyebabkan lingkungan media menjadi asam sehingga menyebabkan peningkatan $\mathrm{pH}$, danmedia berubah menjadi biru. Hal ini disebabkan karena bakteri menggunakan sitrat sebagai sumber energi. Isolat A, B, C, D, E, F, G dan $\mathrm{H}$ tidak dapat menghasilkan indol yang tampak seperti cincin merah pada reaksi deaminasi serta asam piruvat yang dapat dimanfaatkan dalam proses fermentasi. Bakteribakteri tersebut juga mampu menghidroisis triptofan dan bersifat nonmotil (Tabel 3).

Pada uji indol, hasil yang positif menunjukan bahwa bakteri mampu mengkonversi glukosa menjadi asetonin sehingga pada media uji terbentuk cincil indol

\section{KESIMPULAN}

Berdasarkan hasil penelitian didapati beberapa isolat bakteri rizosfir pada tumbuhan $A$. pintoi, yaitu Azotobacter sp., Rhizobium sp., Enterobacter sp., Azospirillum sp., Pseudomonas sp. Enterebocter sp. dan Bacillus sp.

\section{DAFTAR PUSTAKA}

Ahemad M, Kibret M (2014) Mechanisms and applications of plant growth promoting rhizobacteria: Current perspective. Journal of King Saud University 26(1):1-20

Bumunang EM, Babalola OO (2014) Characterization of rhizobacteria from field grown Genetically Modified (GM) berwarna merah (Forbes dan Weissfeld 2007). Pada media TSIA, isolat $A, B, D, G$ dan $H$ memberikan hasil positif yang ditandai dengan adanya pembentukan gas serta rongga pada media, di mana bakteri mampu memfermentasi karbohidrat sehingga media tampak pecah akibat terbentuknya $\mathrm{CO}_{2}$. Hal ini menunjukkan bakteri-bakteri ini melakukan fermentasi terhadap glukosa, laktosa, dan sukrosa. Bakteri juga bakteri memiliki kemampuan dalam mendegradasi dan memfermentasi karbohidrat yang disertai produksi asam.

Bumunang dan Babalola (2014) menemukan bahwa Pseudomonas, Aeromonas, Sphingomonas, Burkholderia, Stenotrophomonas, Achromobacter, Bacillus, dan Ewingella yang diisolasi dari rizosfir jagung memiliki aktivitas, katalase dan produksi indol. Islam et al. (2016) juga menemukan bahwa bakteri $P$. stutzeri, $B$. subtilis, $S$. maltophilia, B. amyloliquefaciens, dan $B$. amyloliquefaciens yang diisolasi dari rizosfir tanaman mentimun juga positif pada uji katalase, sitrat, dan oksidase. and non-GM maizes. Braz Arch Biol Technol 57(1):1-8

Hao X, Taghavi S, Xie P, Orbach MJ, Alwathnani $\mathrm{HA}$, Rensing $\mathrm{C}$, Wei G (2014) Phytoremediation of heavy and transition metals aided by legume-rhizobia symbiosis. International Journal Phytoremediation 16:179_ 202

Heuzé V, Tran G, Delagarde R, Bastianelli D, Lebas F (2016) Pinto peanut (Arachis pintoi). Feedipedia15:47. http://www.feedipedia.org/no de/702 Last updated on April 20, 2016

Islam S, Akanda AM, Prova A, Islam MT, Hossain MM (2016) Isolation and identification of plant growth promoting 
rhizobacteria from cucumber rhizosphere and their effect on plant growth promotion and disease suppression. Frontiers in Microbiology 6:1360

Jensen ES, Peoples MB, Boddey RM, Gresshoff PM, Hauggaard-Nielsen $\mathrm{H}$, Alves BJ, Morrison MJ (2012) Legumes for mitigation of climate change and the provision of feedstock for biofuels and biorefineries. A review. Agron Sustain Dev 32:329-64

Kheyrodin H (2014) Plant and soil relationship between fungi. International Journal of Research Studies in Biosciences 2(9): 42-49

Lay BW (1994) Analisis Mikroba di Laboratorium. Edisi pertama.
Cetakan pertama. PT Raja Grafindo Persada, Jakarta Murray, Baron, Jorgensen, Landry, Pfaller (2007) Manual of Clinical Microbiology. 9th Ed. American Society for Microbiology, Washington DC Sales RMP, Fries DD, Bonomo, Pires AJV, Campos CN, Brito PHR, Pereira IS, Santos JS (2013) Effect of water stress on the growth of Arachis pintoi plants under different nitrogen levels. Revista Brasileira de Zootecnia 42(3): 149-154

Tallei TE, Pelealu JJ, Kandou FE (2016) Effects of arbuscular mycorrhiza inoculation on length, leaf number and flowering of Arachis pintoi. Asian Journal of Microbiology Biotechnology Environmental Science 18(3):803-806 